\title{
Subaltern Voices and Perspectives: The Poetry of MaHMOUd DARWISH
}

\author{
Balraj Dhillon, Simon Fraser University
}

\begin{abstract}
This paper examines the complex use of poetry, identity, myth, and history as a subaltern method of resistance. Edward Said, in Culture and Imperialism, argues that the culture of postcolonial resistance manifests itself in literature by pulling away from separatist nationalism-and moves toward a literature that is liberating for humans-a more integrative view of society. ${ }^{1}$ This article argues that Mahmoud Darwish's poetry uses identity, myth, and history to emblematize a collective Palestinian voice. By doing this, Darwish becomes the epitome of Said's discussion-he resists separatist discourses through this poetry but at the same time resists the hegemonic structures of Israel and the West.
\end{abstract}

$\mathrm{F}$ rom the creation of the Israeli state in 1948 to his death in 2008, Mahmoud Darwish experienced Israeli oppression on a number of occasions. Darwish, the most popular Palestinian poet, published his first works in 1964. In 1948, as a six-year-old, his village in Palestine was destroyed by Israeli forces and his family was forced into exile in Lebanon. ${ }^{2}$ From that time Darwish lived in Lebanon, Egypt, Russia, and France before he returned to Ramallah. He had become interested in poetry during his childhood. Darwish once recalled how he was asked by his headmaster to partake in Deir al-Asad, the anniversary of the founding of Israel, and responded

1 Edward Said, Culture and Imperialism (New York: First Vintage Books, 1994), 216.

2 Abdullah Al-Udhari, Victims of a Map (London: Saqi Books, 2005), 10. 
with a poem about an Arab boy questioning a Jewish boy: "I don't remember the poem, but I remember the idea of it: you can play in the sun as you please, and have your toys, but I can't ... You have a house, and I have none... Why can't we play together?"3 This poem resulted in Darwish being summoned and threatened by the local military governor. This early lesson about the political power of poetry energized Darwish's writing career. Although some of his best known works focus on historical events-the Israeli invasion of Lebanon, the siege of the West Bank in 2002-Darwish's poetry is not limited to the historical and political; his work addresses topics ranging from love to suffering, as well as spirituality. Though Darwish has produced a plethora of works from 1964 to 2009, this paper will focus on those poems written between the time of his poetic, autobiographical account of the Israeli siege of Lebanon in 1982, to his posthumous work published in 2009.

Darwish came to be known as the Palestinian "Poet of Resistance." Yet this label, however honorable, can over-determine readings of his poetry since the title implies an angry militancy that resists any hint of Zionist oppression. In fact, Darwish's poetry resists separatist nationalist discourses by frequently humanizing both Israelis and Palestinians-humanizing the enemy for each. Darwish's poetic speaker always identifies with the voiceless subaltern population and expresses the horrors and beauties of everyday life - this sensitivity is nowhere more apparent than in the poems that addresses the issues of exile. The poetry also provides accounts of Arabic mythology and historical events, subverting the convention of national identities by offering alternative mythologies and histories to resist the hegemonic Western and Israeli historical discourses. Darwish's poems reveal multiple valences to Palestinian identity, and thus emblematize a collective voice of the subaltern Palestinians.

\section{Humanizing the Other}

The pedagogy of the oppressed is an instrument for their critical discovery that both they and their oppressors are manifestations of dehumanization. - Paulo Freire, Pedagogy of the Oppressed ${ }^{4}$

3 Ibid.

4 Paulo Freire, Pedagogy of the Oppressed (New York: The Continuum International 
In a collection of poems and journal entries that were published posthumously, Darwish captivates the reader by creatively delving to the depth of what is at stake: life. This common value-not war or demonizing the Other ("Other" here is capitalized as it is being theorized through Darwish's work itself) - is shared by both Israelis and Palestinians. In a poem called "A Common Enemy," Darwish states,

\author{
It is time for the war to have a \\ siesta. The fighters go to their \\ girlfriends, tired and afraid their \\ words will be misinterpreted: 'We \\ won because we did not die, and \\ our enemies won because they did \\ not die.... But the individual fighter \\ is not a soldier in the presence of \\ the one he loves: 'If your eyes hadn't \\ been aimed at my heart the bullet \\ would have penetrated it!' ... Or: \\ 'In battle I did not think of victory \\ but of being safe, and of the freckles \\ on your back.' ... Fighters on both \\ sides say similar things in the \\ presence of the ones they love. But \\ the casualties on both sides don't \\ realize until it's too late that they \\ have a common enemy: death. So \\ what does that mean ${ }^{5}$
}

Here Darwish writes about the futility of war, and how both sides suffer as a result of it. He contrasts the behaviour of a soldier in war to that of a soldier in front of a loved one, to demonstrate the difference between behaviours in their respective contexts. This juxtaposition also highlights that outside of war, off the battlefield, all soldiers have very human needs, and are essentially the same in the eyes of their

Publishing Group Inc., 2009), 48.

5 Mahmoud Darwish, A River Dies of Thirst, trans. Catherine Cobham (Brooklyn, NY: Archipelago Books, 2009), 18. 
loved ones. The poem also shows the contrast between the tenderness they show to their lovers and the horrors of war.

In "State of Siege," he also humanizes the enemy, but in a very unique way, questioning the Other's sincerity, yet also questioning whether or not he himself is still human:

You standing at the doorsteps, enter
and drink Arabic coffee with us
(you might sense you're human like
us)
you standing at the doorsteps of
houses, get out of our mornings,
we need reassurance that we are
human like you! ${ }^{6} .$. (To a third
guard:) you have a mother/I have
a mother/and we have one rain/
and we have one moon/and a brief
absence from the dining table.

The poetic speaker is addressing an Israeli soldier and attempting to open up dialogue with the soldier and acknowledge one another's humanity. The soldier here represents not just one soldier, but all Israelis, and Darwish is calling on them to recognize that their lives are the same, that they will both have "a brief absence from the dining table." The poet here is not only challenging the Other to dialogue with the Palestinians, so that the enemy can sense the humanity in his Other (the Palestinians); he is also expressing the need for the enemy's recognize the humanity of the Palestinians. While this poem responds to the inhumane treatment during the siege of Ramallah, and indeed the inhumane treatment of Palestinians in general, the poem affirms the humanity of the Israeli. By equating the humanity of the Palestinians to that of the Israeli, Darwish's poem slices through the nationalist discourses on both sides of the conflict.

The project of humanization is constant throughout "State of Siege." However, by humanizing the enemy, Darwish focuses in this

6 Mahmoud Darwish, The Butterfly's Burden, trans. Fady Joudah (Washington: Copper Canyon Press, 2007), 125.

7 Ibid., 159. 
poem on the enemy humanizing the Palestinians:

(To a killer:) If you'd contemplated the victim's face/and thought, you would have remembered your mother in the gas chamber, you would have liberated yourself from the rifle's wisdom/and changed your mind: this isn't how identity is reclaimed! ${ }^{8}$... I don't love you, I don't hate you .... Yes, I don't love you. Who are you that I should love you? Are you some of my I, and a meeting over tea/and a nay's hoarseness, and a song that I should love you? But I hate detainment and I don't hate you. ${ }^{9}$

Darwish, invoking the Holocaust, is not only humanizing the Israelis and acknowledging their past, but he uses this past to encourage them to humanize Palestinians. In effect, he is saying that the difference between the Holocaust and the siege of Ramallah (or any oppression) is that of degree and not of type. He goes on to say that it is not Israel that he neither hates nor loves, but he hates what the state does: detainment, oppression, war, hegemony.

By invoking the Holocaust and using it to draw a parallel line to the oppression that Palestinians face, Darwish is attempting to create a dialogue between Israelis on the ground and Palestinians on the ground. The Holocaust is not brought up here to invoke a sense of guilt, but rather empathy, as the poet attempts to convince the Israeli oppressors to empathize with the ones they oppress, the Palestinians, by remembering their own tragic history. These two poems, "A Common Enemy" and "State of Siege," deny the glory of war and do not even mention political parties, leaders, or spokespersons. Darwish is speaking strictly from the ground. Paulo Freire outlines that the oppressed must perceive the reality of their oppression as a limiting

8 Ibid., 131.

9 Ibid., 155. 
situation which can be changed. ${ }^{10}$ For Freire, liberating change requires the oppressed to engage in the struggle for humanization, thereby liberating themselves and their oppressors by humanizing both sides. This "humanizing pedagogy" makes possible dialogue between the oppressor and the oppressed which-what Freire calls the "humanizing pedagogy" - as he states that it is the most effective act of resistance because it establishes a "permanent relationship of dialogue with the oppressed."11 Darwish, in these two poems, works to begin this dialogue and create a humanizing pedagogy. He seeks both to liberate Palestinians by reminding them and Israelis that "we are human too!", while also seeking to liberate the oppressors from "the rifle's wisdom."

Any sense of an official historical or nationalist discourse does not seem apparent in any Darwish poem, and if these discourses do exist in his poetry they definitely don't have strong tones. Instead, what is encountered is a very human view of the conflict and the general refusal to demonize the Other. Darwish is writing from the perspective of "the ground" or "the people," a word that is synonymous with "subaltern" according to Gayatri Spivak. The subaltern population consists of social groups that represent a demographic difference between the total population and the elite. ${ }^{12}$ The liberation that Freire discusses is that of the oppressed, the oppressed populations who are voiceless. Darwish, engages in a dialogue different from the official Palestinian or Israeli nationalist discourse (one might call those an "un-dialogue"), and represents the voiceless population. He writes from the perspective of the subaltern.

Identity of the Exile

We'll survive and climb/a mountain in the north and return when/the soldiers return to their distant families.

- Mahmoud Darwish, "The Eternity of Cactus"

10 Freire, 49.

11 Ibid.,68.

12 Gayatri Spivak, "Subaltern Studies: Deconstructing Historiography, in Subaltern Studies IV: Writings on South Asian History and Society, ed. Ranajit Guha (Oxford: Oxford University Press, 1985), 340. 
The poem "The Eternity of Cactus" reflects the beginning of exile as a father leads his son from Palestine to Lebanon in an escape from their own house. As they leave, the father tells his son, "Remember, my son, here the British crucified/your father on the thorns of a cactus for two nights .... Why did you leave the horse alone? - To keep thehouse company, my son...." ${ }^{13}$ In this autobiographical piece, Darwish is addressing some major themes. One is the crucifixion of his father, an event that would be read about in a history text or seen in a documentary. This type of memory speaks to the voicelessness of the oppressed, however, the poem gives them that voice. The other theme here is anticipation of returning home. The father leaves the horse so the house won't be lonely, and further tells his son that they'll return "Tomorrow. Perhaps in two days my son!"14 This promise of return transforms the loss of home into drama of return. ${ }^{15}$ However, there is a definite tone of sadness as the poem opens with the son asking the father where they are going; the father answers, "Where the wind takes us, my son ...."16 The father does not answer the question and contradicts himself by promising to return, yet feels that their destiny is not in his hands. This is not to depict the father negatively, rather to get to the depth of the emotion involved, for the father does not have it in him to answer his son, yet promises a quick return. The poet also gets at a sense of irony as the son asks his father who will live in their house when they leave, and the father replies "It will remain as it is, as it has always been, my son!"17 The promise here is that nobody will occupy the land, that they will find it unchanged upon their return. There is a definite sense of sadness and longing in "The Eternity of Cactus."

However, despite this sense of sadness at leaving one's home, this sadness has not exposed the poet to despair; rather, hopeful visions run consistently through the poetry. ${ }^{18}$

13 Mahmoud Darwish, Why Did You Leave the Horse Alone? trans. Jeffrey Sacks (Brooklyn, NY: Archipelago Books, 2006), 28-30.

14 Ibid., 30.

15 Hala Khamis Nasser, "Exile and the City: The Arab City in the Writing of Mahmoud Darwish," in Mahmoud Darwish: Exile's Poet, ed. Khamis Nassar and Najat Rahman (Massachusetts: Olive Branch Press, 2008), 196.

16 Darwish, Horse, 28.

17 Ibid., 28.

18 Khalid A. Sulaiman, Palestine and Modern Arab Poetry (London: Zed Books 
The whole collection that "The Eternity of Cactus" belongs to is wrought with autobiographical inserts, and by doing this, Darwish is attempting to write his own story to safeguard his inheritance-an inheritance that will not dispossess him. ${ }^{19}$ Darwish really emphasizes here the mindset of the refugees when they first left; there was a feeling that they would not return, but they told themselves and their children they would, and that nothing would change. Darwish's experience allows him to write most effectively about exile in a type of poetry, as will be analyzed later, that provides an alternate history to the conflict.

\section{Deconstructing Myth}

Poetry is our ladder to a moon hung by Anat/over her garden, a mirror for hopeless lovers.

- Mahmoud Darwish, "The Phases of Anat"

In discussing Darwish's employment of myth, two poems will be analyzed: "The Well" and "Phases of Anat." Darwish employs myth to resist Zionist appropriation of it, and does it from the perspective of the subaltern as he writes from a sense of community in envisioning the past. The employment of myth by Darwish subverts the convention of national identities, providing an alternative to those myths that were thought to be rigid and definitive.

One poem in which Darwish employs myth is "Phases of Anat." In order to fully understand the poem, a background of the goddess Anat must be observed. Anat, the moon goddess, distinguished herself in the Canaanite epics with strength and courage; and though she became known as a warrior she was also identified with fertility and considered to be the goddess of life. ${ }^{20}$ The cult of Anat spread from Phoenicia and Canaan to Egypt, and a sanctuary thought to be built by Ramses II in Egypt was discovered by archaeologists to have

Ltd., 1984), 195.

19 Najat Rahman, Literary Disinheritance: The Writings of Home in the Works of Mahmoud Darwish and Assia Djebar (UK: Lexington Books, 2008), 95.

20 Herbert Cohn, "Is the 'Queen of Heaven' in Jeremiah the Goddess Anat?" In Jewish Bible Quarterly Jan-March 32, 1(2004). http://jbq.jewishbible.org/assets/ Uploads/321/321_Queen1.pdf. 
a pillar dedicated to Anat. Furthermore, it is of particular interest that the name "Anat" is similar to many localities in Israel, such as "BetAnat". ${ }^{21}$

Darwish mourns the loss of Anat, and calls for her return in his poem "Phases of Anat." He states,

\author{
I want you both, together, love \\ and war. Oh Anat to hell with me \\ .... I love you, Anat! ... We broke \\ like a fence over your absence ... \\ Our prayers calcified. Nothing \\ lives after your death ... Perhaps \\ new goddesses will descend upon \\ us in your absence and we'll be \\ ruled by a mirage ... You'll return. \\ You'll return the land of truth and \\ allegory, the land of Canaan - the \\ beginning/the land that opens \\ between your communal breasts/ \\ and your communal thighs, so that \\ the miracles will return to Jericho. ${ }^{22}$
}

Anat's personality is one full of dichotomies-the goddess of life and death, fertility and war, mother and warrior. Darwish calls for the return of the goddess whose influence spreads from Canaan, Syria, and Phoenicia; Anat's very being epitomizes inherent dialects from all of these cultures. The poet shows a deeper dichotomy of Anat: "Two women never to be reconciled/As for the horses/they'll dance for a long while over the two abysses. There's/neither death there, nor life/There I'm neither alive nor dead/Nor is Anat!" 23 The "two women never to be reconciled" speaks to Anat's Other being within herself allowing her to self-reflect with the eyes of an Other. To love Anat is to be in hell, yet to erase her altogether is to be in an inconclusive chaos. Without Anat's presence geography and history are doomed to

21 Ibid., 55."Bet-Anat" is considered the tribal territory of Naphtali (Josh 19:38) and Judah (Josh 15:59).

22 Darwish, Horse, 95-96.

23 Ibid., 98. 


\section{Balraj Dhillon}

be "the wells that dried up."24

Darwish's choice of Anat is no coincidence. Anat is a controversial figure, a figure who is elusive in the sense that she is open to a variety of interpretations and is not restrained by one tradition but shared among many different cultures. In Cohn's article, he observes how many places in Israel are named after Anat, yet Darwish remembers Anat in a very particular way, employing the ability to interpret her in his own way. He redeems his own culture and mediates between the past and the present by using an alternative story of Anat to resist against the narrative of the colonizer. ${ }^{25}$ Edward Said observes how imperialist regimes use tradition as a determinant of national identity, seeking to produce "pure (even purged) images" constructed "of a privileged, genealogically useful past, a past in which we exclude unwanted elements, vestiges, narratives." ${ }^{26}$ The past that is being appropriated by the colonizers and used to perpetuate their colonial identity and division, which Darwish attempts to deconstruct. As Celik observes, colonialists use the past to divide and rule, and therefore the past "has to be rewritten by the colonized and the oppressed."27

In this sense, Darwish is not simply deconstructing the old myth of Anat, but by challenging the very appropriation of Anat by Zionist discourse, Darwish is providing an alternative myth from a subaltern perspective. As Asok Sen discusses, elite leadership is often engrossed in the values and ideals of their colonizers, and the elites tend to rationalize the structures shaped by colonialism. ${ }^{28}$ Darwish is directly challenging these structures, using myth as a medium. In Said's discussion of the "culture of resistance," he states it that it is imperative of this culture to search for an authenticity more congenial than that offered by colonial histories - allowing for a new pantheon

24 Ipek Azime Celik, "Alternative History, Expanding Identity: Myths Reconsidered in Mahmoud Darwish's Poetry," in Mahmoud Darwish: Exile's Poet, ed. Khamis Nassar and Najat Rahman, (Massachusetts: Olive Branch Press, 2008), 281-82.

25 Ibid., 283.

26 Said, 15.

27 Celik, 283.

28 Asok Sen, "Discussion: Subaltern Studies: Capital, Class and Community," in Subaltern Studies V: Writings on South Asian History and Society, ed. Guha, Ranajit (Oxford: Oxford University Press, 1985), 226. 
of heroes/heroines, myths, and religions. ${ }^{29}$ Darwish doesn't create a new myth, but he does rework an existing one, and gives a new version, an alternative to the appropriation of the existing myth. Sen makes the connection once more: "It is often in such circumstances that subaltern consciousness seeks in the sense of community its own vision of a paradise lost." "The Phases of Anat" speak to this sense of community and its vision of the past, enabling Darwish to employ myth as an effective tool to resist appropriation of Zionist dominance.

\section{Alternative Histories}

Metal is time's master, and nothing cuts one metal except another that carves a different history.

$$
\text { - Mahmoud Darwish, Memory for Forgetfulness }{ }^{31}
$$

Many of Darwish's poems are accounts of historical events. Two historical accounts and their respective poems (one is a prose-poem) will be analyzed: the Israeli invasion of Lebanon and the Israeli siege of the West Bank in 2002. Darwish's poems Memory for Forgetfulness and "State of Siege" provide his own accounts of these events, and a contrast will be drawn between Darwish's works and those of official historical discourses (official discourses being scholarly accounts of history, namely from the West).

David Lesch's book The Arab-Israeli Conflict: A History surveys the conflict from the time of the downfall of the Ottoman Empire in Palestine to the year 2006. In surveying this history, Lesch could not escape writing about the 1982 Israeli invasion of Lebanon; however he does so in a very peculiar way. The first point is that the invasion does not have its own chapter, nor does the first intifada, rather they are included together in one chapter. This lends a sense of unimportance to these events. Throughout Lesch's book he discusses the conflict from a very "top-down" perspective-discussing policies and policy-makers, politicians, and leaders, and rarely, if at all does he include the perspective of the subaltern community. For instance,

29 Said, 226.

30 Sen, 228.

31 Mahmoud Darwish, Memory for Forgetfulness, trans. Ibrahim Muhawi (California: University of California Press, 1995), 118. 
in his discussion of refugees in 1948, he states, "According to most sources, 700,000-750,000 Palestinians either were forced out of their homes or left of their own accord .... Of the 700,000-750,000, about $60 \%$ went to Transjordan/Jordan, $20 \%$ found themselves under Egyptian control in the Gaza Strip, and about $20 \%$ went to Syria and Lebanon." ${ }^{32}$ Lesch provides no insight into the living conditions of the refugees, nor their perspectives on this conflict.

Lesch begins his discussion of the Israeli invasion with the 1977 Israeli elections and the rise of Menachem Begin, calling Begin's approach to Lebanon "assertive." Begin launched his assault in 1982 with 90,000 Israeli troops, with the intent of destroying the Palestinian Liberation Organization (PLO) and making Lebanon into a satellite state headed by Maronite leader Bashir Gemayel. Lesch goes on to discuss the political workings of surrounding states as well as Israel's efforts to get Syria out of Lebanon and keep the Golan Heights, and some logistical statistics about the war: "Some sixty Syrian fighter jets were shot down in the first few days of the invasion with the loss of just one Israeli aircraft." ${ }^{33}$ There is a brief discussion on the Sabra and Shatila massacres, however Lesch directs the reading towards the negative effect the episode had on Ariel Sharon's career in government, as well as on Prime Minister Begin. ${ }^{34}$ There is no attempt on Lesch's part to offer a subaltern perspective on the massacres of Sabra and Shatila, nor does he make any attempt to offer insight into the living conditions of the refugees and how the invasion affected these conditions. This "official" history is limited in its scope; though this is not necessarily a negative trait, it doesn't offer anything by way of the subaltern.

Darwish, however, dedicated a 182-page prose-poem to a single day of this invasion, displaying the importance it played for the people on the ground. Darwish's account in Memory for Forgetfulness of just one day in Lebanon during the invasion offers a subaltern perspective from the ground and has little to do with the official politics of any nation-states involved. For instance, he briefly mentions Gemayel in the context of a discussion with his friend and his friend's wife, who happened to be Maronite. In the prose-poem, the wife applauds the

32 David Lesch, The Arab-Israeli Conflict: A History (Oxford: Oxford University Press, 2008), 145.

33 Ibid., 291-94.

34 Ibid., 296. 
,Israelis' "free service" to "the hero of her dreams - Bashir Gemayel," and believes that after Gemayel comes to power the "aliens" will be driven out, and the Israelis will return without asking for a fee. ${ }^{35}$ The poet then expresses his own feelings towards the wife and her opinions:

$$
\begin{aligned}
& \text { For all that, I feel no rancor toward } \\
& \text { her; rather, pity at how deeply she } \\
& \text { has gone into mere fantasy and } \\
& \text { refusal of the Other .... Before } \\
& \text { a mind so closed, so completely } \\
& \text { made up, all attempts at argument } \\
& \text { come to a halt. In vain does her } \\
& \text { husband, whose past is secular, try } \\
& \text { to convince her that the Israelis } \\
& \text { don't love Lebanon and aren't there } \\
& \text { to defend it, and that just one rocket } \\
& \text { from their jets can turn all of us } \\
& \text { sitting in this apartment, Muslim } \\
& \text { and Maronite alike, into ground } \\
& \text { meat. }{ }^{36}
\end{aligned}
$$

This particular passage allows for an interesting insight. The perspective that Darwish is writing from enables the reader to see how the siege affected those on the ground. The wife has bought into the Maronite/Israeli propaganda while the husband continues to argue and convince her otherwise, while Darwish himself sees no point in arguing. He sees the powerful role that nationalist discourse plays in the daily lives of people, and how in this particular case his friend's wife's mind is made up. However, Darwish also speaks to the power of the nation-state, and indeed the power and indiscriminant nature of war, for through the husbands words he express the notion that the rockets, jets, and weapons do not discriminate between Muslims, Maronites, Palestinians, or Lebanese.

The passage, however, speaks to very few issues brought up by the prose-poem. This particular Darwish piece raises the issue of memory as a form of resistance to official historical and nationalist discourses;

35 Darwish, Memory, 38.

36 Ibid., 39. 
memory here serves as a tool to resist these discourses as the poet invokes memory on a number of occasions:

I sit in a far corner, away from others and myself, thinking about a dream that came, born from another dream. Are you still alive? When did it happen? Will memory protect me from this threat? ${ }^{37}$

The poet employs memory in a similar way when discussing his friend Kamal as he states, "Kamal withdrew into his secret, closing himself off in memories that had turned into dreams." ${ }^{38}$ Here Darwish is employing memory in a very direct way, stating that perhaps memory is the only tool of resistance that the subaltern possesses. Though he does not answer this question directly when he asks, "Will memory protect me...?" he certainly invokes memory as protection or resistance when he wrote the piece. Perhaps Darwish employs memory best in the context of exile:

The jet's flares light wide paths in the alley for my dragging footsteps. Here, I didn't die.... I've been dragging my shadow over this sidewalk for the past ten years, placing a signature on my exile, feeling sure I wouldn't be staying more than one year. The years piled up, one on top of the other. For ten years now I've been knocking on this door, avoiding the sea. I used to prefer the land route, the path I walked thirty years ago and walked again to back there. Did I forget to return, or did I forget to remember? How was everything, anything, ten

37 Ibid., 119.

38 Ibid., 165. 


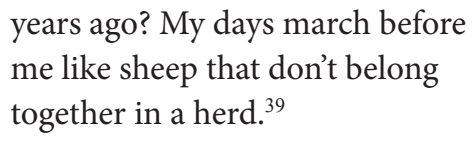

Here the poet has to remember if he is even alive, and when he discovers he is, he can not believe that ten years have passed in Lebanon. By calling into question his own memory, he acknowledges the power of memory and how it seems that he no longer has control of even his own life. He goes on, "Here, I didn't die; I haven't died yet. But this howling that descends from the sky and rises from the earth doesn't stop. It won't permit any of the images of my days to settle into a form." ${ }^{40}$ Thus in the poem, memory is called into to question, and with the bombing, even memory seems powerless as "it won't permit images of my days to settle into a form"; yet, memory is also invoked as a protector-“will memory protect me?"It must be acknowledged as well that this poem is based in memory, and as a tool to directly confront historical discourses. Ted Swedenburg, in his book Memories of Revolt, points out that this type of "memory as resistance" acknowledges the fact that the memories have not been "hegemonized or erased by nationalist discourse."41 Memories serve as a tool or weapon of resistance, and in Darwish's piece in particular, as a voice for the subaltern as the memories are those of exile and powerlessness.

The style in which Memory for Forgetfulness is written must also be considered. The poem is about one day in Beirut during the Israeli siege, and begins with the poet waking up in his apartment at around 3 a.m. to the sound of Israeli shelling. From that point, the reader experiences poetry, prose, history, and personal stories; but what is most compelling is the how Darwish captures the mindset of being under siege. The frantic mindset is best expressed when the poet begins explaining the dilemma that Palestinian refugees find themselves in - "when he holds his peace, his soul is taken out to the stray dogs; and when he moves toward the homeland, his body

39 Ibid., 172.

40 Ibid., 173.

41 Ted Swedenburg, Memories of Revolt: The 1936-1939 Rebellion and the Palestinian National Past (Arkansas: University of Arkansas Press 2003), 136. 
is dragged out to the dogs." ${ }^{22}$ Darwish shifts quickly to a thought of conquerors and their power, and from their he expresses his desire to drink coffee: "Conquerors can do anything .... I shall make my coffee now. I will drink the coffee now. Right now, I will be sated with the aroma of coffee." ${ }^{43}$ Not only does Darwish effectively express the dilemma of the voiceless exile, the quick shifts in unconnected thoughts really expresses the frantic mindset one must be in when in a situation like that. Coffee serves as a means to distract him from the siege, as he is powerless and his only voice is through this poem.

Memory for Forgetfulness also directly challenges historical discourses as the only histories. Darwish questions the dominating historiographies as hegemonic structures that ignore the subaltern, in essence offering a subaltern history himself. In discussing Prime Minister Begin and Bashir Gemayel, he criticizes history and accuses it of injustice:

$$
\begin{aligned}
& \text { But what have we to do with the } \\
& \text { history of what came out of history? } \\
& \text { For in the mind of the king of the } \\
& \text { legend everything has been frozen } \\
& \text { as it had been, and since that } \\
& \text { time history has done nothing in } \\
& \text { Palestine and on the eastern shores } \\
& \text { of the Mediterranean except wait } \\
& \text { for the new king of the legend, } \\
& \text { Menachem, son of Sarah, son of } \\
& \text { Begin, who will protect the Third } \\
& \text { Temple from the anger within and } \\
& \text { without, in league with the king of } \\
& \text { Ashrafiya-Bashir, son of Pierre, } \\
& \text { son of Gemayel.44 }
\end{aligned}
$$

Implying that Palestinians have not benefitted, in fact, have been appropriated by history, Darwish also asks the crucial question for those concerned with the subaltern: "Who, then, will write the history

42 Darwish, Memory, 16.

43 Ibid., 17.

44 Ibid., 144. 
of the bottom, the history of the moss?" 45 Thus Darwish presents two issues: Palestinians have been erased from history by the official discourses, and the hegemonic structures have not taken up the problem of writing subaltern history. In this case, Darwish's "bottom" or subaltern is particularly referring to the refugee community, as it isnot only continuously ignored in official discourses (see Lesch), but more or less erased from any peace talks (Resolution 242).

Darwish raises the issue of the subaltern, but by doing so through poetry, one may not recognize it as a legitimate form of history. In his analyses of Indian historiography under British rule, Ranajit Guha observed that there was a strict uniformity of the pattern in which chapter headings were inscribed-evidence that Indian historiography acquiesced to the expropriation of their colonizers. ${ }^{46}$ Darwish serves as a great example of someone who has not been expropriated, but is rather someone who breaks free from the uniformity of historiography to write alternative history through poetry. For Darwish, history and poetry belong together. In Memory for Forgetfulness he states,

$$
\begin{aligned}
& \text { I want to find a language that } \\
& \text { transforms language itself into } \\
& \text { steel for the spirit - a language to } \\
& \text { use against these sparkling silver } \\
& \text { insects, these jets. I want to sing. I } \\
& \text { want a language that I can lean on } \\
& \text { and that can lean on me, that asks } \\
& \text { me to bear witness and that I can } \\
& \text { ask to bear witness, to what power } \\
& \text { there is in us to overcome this } \\
& \text { cosmic isolation. }{ }^{47} . . \text { And when we } \\
& \text { write, and call upon others to write, } \\
& \text { in the name of creative freedom } \\
& \text { we are doing nothing more than } \\
& \text { bringing into focus the points of } \\
& \text { light and first effort scattered by }
\end{aligned}
$$

45 Ibid., 118.

46 Ranajit Guha, Dominance without Hegemony (Cambridge Massachusetts: Harvard University Press, 1998), 196.

47 Darwish, Memory, 52. 
dissension over an idea founded on this simple assertion: we want to liberate ourselves, our countries, and our minds and live in the modern age with competence and pride. In writing, we give expression to our faith in the potency of writing .... And we announce further that we are children of this age, and not of the past or the future..$^{48}$

Darwish displays a consciousness in his actions; indeed he is fully aware of his resistance by writing in such a cultured manner. Darwish himself answers his question "who will write the history of the bottom?" by writing it himself through poetry and prosepoetry. The question is answered in the title of the prose-poem itself: Memory for Forgetfulness. The poet states that he is "searching for a language to use against these jets," and searching for a language to defeat Zionist hegemony, for through writing, Palestinians can bring into focus those issues that are most important to them: liberation of nation, individual, and mind. As the title suggests, Darwish is offering a memory of what it was like on the ground, in contradistinction to forgetful historical discourses such as Lesch's. For the poet then, though he praises fedayeen throughout Memory for Forgetfulness, the armed struggle will not liberate Palestinians, neither in a physical nor spiritual sense. The poet is looking for a language then not just to "use against these jets," but also to "lean on ... that can bear witness"-a language that can liberate Palestinians from the hegemonic structures of history, but also of war, by asserting that Palestinians have an identity of their own. The Palestinian identity is rooted not "in the past or the future", but rooted in the present. The role of the poet must also be considered here, for in Arabic culture a special role is attributed to the poet. Poets are known to speak for their communities by producing cultural, spiritual, material, informative, and national poetry. ${ }^{49}$ Guha

48 Ibid., 140-41.

49 Subhi Hadidi, "Mahmoud Darwish's Love Poem: History, Exile, and the Epic Call," in Mahmoud Darwish: Exile's Poet, ed. Khamis Nassar and Najat Rahman (Massachusetts: Olive Branch Press, 2008), 97. 
states that colonial histories have nothing to do with promotion of culture among the colonized population. ${ }^{50}$ Thus Darwish, fulfilling the role of the poet in Arabic culture, resists the colonial hegemony of Israel and through poetry answers his own question by writing himself the "history of the bottom, the history of the moss."

The subaltern perspective provided by Darwish is not only rooted in resistance, but can also be understood as an alternative form of history. Said writes that resistance literature, "far from being merely a reaction to imperialism, is an alternative way of conceiving human history." ${ }^{51} \mathrm{He}$ also points out that a typical trait of the culture of resistance is to pull away from a separatist nationalism and move toward "a more integrative view of human community and human liberation." Darwish achieves this by providing a subaltern perspective to historical events that not only resists nationalist discourse but also contributes to a more integrative view of the conflict. ${ }^{52}$

By providing a multiplicity of meanings to Palestinian identity, Mahmoud Darwish gave a voice to subaltern Palestinians. This voice resists historical discourses about the region, providing an alternative view to the history of the Arab-Israeli conflict. Though only one poem, Memory for Forgetfulness, was analyzed to display this alternative form of history, Darwish's collection contains many more that also express the suffering of everyday life. Perhaps this is best displayed in his poems regarding exile; in them Darwish catches the longing to return home. Also, by humanizing Israelis, Darwish gives new meaning to his title the "poet of resistance" by resisting and subverting separatist nationalist discourses.

Darwish himself had experienced Israeli oppression first-hand. Though he had lived all over the world and was part of the PLO for a brief period, Darwish encountered enough suffering-exile, constant house arrests, the invasion of Lebanon, the siege of Ramallah-at the hands of Israelis to understand and give voice to the subaltern Palestinians. Though he is the most popular poet of Palestine, his poetry is more than poetry, it is history, mythology, and the subaltern voice. Darwish's title as the "poet of resistance" is in a sense unfortunate as it limits his scope. Darwish's work goes beyond resistance of the subaltern; he is the poet of the people.

50 Guha, 161.

51 Said, 216.

52 Ibid., 216. 


\section{Bibliography}

Abdel-Malek, Kamal, and David Jacobson. Israeli and Palestinian Identities in History and Literature. New York: St. Martin's Press, 1999.

al-Udhari, Abdullah. Victims of a Map. London: Saqi Books, 2005.

Celik, Ipek Azime. "Alternative History, Expanding Identity: Myths Reconsidered in Mahmoud Darwish's Poetry." In Mahmoud Darwish: Exile's Poet, ed. Hala Khamis Nassar and Najat Rahman, 273-292. Massachusetts: Olive Branch Press, 2008.

Cohn, Herbert. "Is the 'Queen of Heaven' Jeremiah the Goddess Anat?" Jewish Bible Quarterly. January-March 32, 1 (2004). http://jbq.jewishbible.org/assets/Uploads/321/321_Queen1.pdf.

Darraj, Faysal. "Transfigurations in the Image of Palestine in the Poetry of Mahmoud Darwish." In Mahmoud Darwish: Exile's Poet, ed. Hala Khamis Nassar and Najat Rahman, 57-78. Massachusetts: Olive Branch Press, 2008.

Darwish, Mahmoud. A River Dies of Thirst. Brooklyn, NY: Archipelago Books, 2009.

Memory for Forgetfulness. California: University of California Press, 1995.

. The Butterfly's Burden. Copper Canyon Press, 2007.

Unfortunately, It Was Paradise. California: University of California Press, 2003.

. Why Did You Leave the Horse Alone? Brooklyn, NY: Archipelago Books, 2006.

Freire, Paulo. Pedagogy of the Oppressed. New York: The Continuum International Publishing Group Inc., 2009.

Guha, Ranajit. Dominance without Hegemony. Cambridge, Massachusetts: Harvard University Press, 1998. 
Hadidi, Subhi. "Mahmoud Darwish's Love Poem: History, Exile, and the Epic Call." In Mahmoud Darwish: Exile's Poet, ed. Hala Khamis Nassar and Najat Rahman, 95-122. Massachusetts: Olive Branch Press, 2008.

Lesch, David. The Arab-Israeli Conflict. Oxford: Oxford University Press, 2008.

Migdal, Joel, and Kimmerling, Baruch. The Palestinian People. Cambridge, Massachusetts: Baruch Kimmerling and Joel Migdal, 2003.

Nassar, Hala Khamis. "Exile and the City: The Arab City in the Writing of Mahmoud Darwish." In Mahmoud Darwish: Exile's Poet, ed. Hala Khamis Nassar and Najat Rahman, 191-214. Massachusetts: Olive Branch Press, 2008.

Rahman, Najat. Literary Disinheritance: The Writings of Home in the Work of Mahmoud Darwish and Assia Djebar. UK: Lexington Books, 2008.

Said, Edward. Culture and Imperialism. New York: First Vintage Books, 1994.

Sen, Asok. "Subaltern Studies: Capital, Class and Community." In Subaltern Studies V: Writings on South Asian History and Society, ed. Ranjit Guha. Oxford: Oxford University Press, 1985.

Spivak, Gayatri Chakravorty. "Subaltern Studies: Deconstructing Historiography." In Subaltern Studies IV: Writings on South Asian History and Society, ed. Ranjit Guha. Oxford: Oxford University Press, 1985.

Sulaiman, Khalid A. Palestine and Modern Arab Poetry. London: Zed Books Ltd., 1984.

Swedenburg, Ted. Memories of Revolt: The 1936-1939 Rebellion and the Palestinian National Past. Arkansas: University of Arkansas Press, 2003. 